The Open Conference Proceedings
Beuntham open
JrossMark
Content list available at: www.benthamopen.com/TOPROCJ/
DOI: $10.2174 / 2210289201607020070$

\title{
Bacterial Rhizosphere Biodiversity from Several Pioneer Desert Sand Plants Near Jizan, Saudi Arabia
}

\author{
Jorge R. Osman ${ }^{1}$, Axel de Zelicourt ${ }^{2}$, Ton Bisseling ${ }^{2}$, Rene Geurts ${ }^{2}$, Heribert Hirt ${ }^{3}$ and Michael S. \\ DuBow ${ }^{1, *}$ \\ ${ }^{I}$ Université Paris-Sud, Laboratoire de Génomique et Biodiversité Microbienne des Biofilms, Institute for Integrative \\ Biology of the Cell (I2BC), CEA, CNRS, Université Paris-Saclay, Bâtiment 409, 91405 Orsay, France \\ ${ }^{2}$ Chemisch Biologisch Laboratorium Bodem, Wageningen Universiteit, 6708 PB Wageningen, Netherlands \\ ${ }^{3}$ Center for Desert Agriculture, 4700 King Abdullah University of Science and Technology, Thuwal 23955-6900, \\ Kingdom of Saudi Arabia
}

\begin{abstract}
Life in arid regions and, in particular, hot deserts is often limited due to their harsh environmental conditions, such as large temperature fluctuations and low amounts of water. These extreme environments can influence the microbial community present on the surface sands and any rhizosphere members surrounding desert plant roots. The Jizan desert area, located in Saudi Arabia, supports particular vegetation that grows in the large sandy flat terrain. We examined five different samples, four from the rhizosphere of pioneer plants plus a surface sand sample, and used pyrosequencing of PCR-amplified V1-V3 regions of 16S rDNA genes from total extracted DNA to reveal and compare the bacterial population diversity of the samples. The results showed a total of 3,530 OTUs in the five samples, calculated using $\geq 97 \%$ sequence similarity levels. The Chaol estimation of the bacterial diversity fluctuated from 637 to 2,026 OTUs for a given sample. The most abundant members found in the samples belong to the Bacteroidetes, Firmicutes and Proteobacteria phyla. This work shows that the Jizan desert area of Saudi Arabia can contain a diverse bacterial community on the sand and surrounding the roots of pioneer desert plants. It also shows that desert sand microbiomes can vary depending on conditions, with broad implications for sandstone monument bacterial communities
\end{abstract}

Keywords: Bacterial community, desert sand microbiome, pyrosequencing, rhizosphere, 16S rDNA.

\section{INTRODUCTION}

The Earth's arid regions represent $>30 \%$ of the continental surface, and are defined as regions that receive $\leq 250$ $\mathrm{mm}$ of average annual rainfall (AAR) [1 - 3]. Life in deserts is limited due to lack of available water, high UV exposure and high temperature fluctuations that have led hot deserts to be considered as extreme environments [1, 3, 4]. The presence of plants is often restricted in deserts due to the harsh conditions, such as low nutrient levels and strong winds [5]. The diversity of plant-associated bacteria may play a fundamental role in different processes such as organic material recycling, mineralization and fixation of essential nutrients, such as carbon (C), nitrogen (N) and phosphorus (P). These nutrients are responsible for important processes in biogeochemical cycles, where photosynthesis, atmospheric $\mathrm{N}$ fixation and microbial mineralization are parts of primary production [6, 7].

Soils are one of the most studied environments in microbiology, owing to large differences in habitats, for examining patterns of genetic diversity in different ecosystems and to analyze the functional organization of the native microorganisms [8]. In these environments, the rhizosphere is defined as the zone of soil immediately adjacent to plant roots that supports high levels of bacterial activity [9] and is considered a rich zone for microbial populations [10].

\footnotetext{
* Address correspondence to this author at the Laboratoire de Génomique et Biodiversité Microbienne des Biofilms, Institute for Integrative Biology of the Cell (I2BC), CEA, CNRS, Université Paris-Saclay, Université Paris-Sud, Bâtiment 409, 91405 Orsay, France; Tel: +33 (0)1 69 15 46 12; Fax: +33(0)16915 78 08; Email: michael.dubow@u-psud.fr
} 
For this reason, the rhizosphere is considered a unique region from the bulk soil, where organic compounds are released by the roots, making this zone high in nutrients [11].

Most soil microorganisms are non-cultivable under laboratory conditions [12]. Advances in high-throughput DNA sequencing techniques provide important advances in microbial research in a broad range of ecosystems and applications including desert sand and, eventually, sandstone monument surfaces [13]. Microbial diversity investigations of deserts have included a large range of studied regions, methods of analyses and applications. Zhang et al., (2012) studied the distribution and diversity of bacteria in the southeast edge of the Tengger Desert of China, and their work provided a key approach of the correlations between the bacterial communities identified by DGGE bands and the structure of desert soil enzyme activities [14]. An et al., (2013) analyzed the bacterial diversity of surface sand samples from the Gobi and Taklamaken deserts using bacterial Tag-Encoded FLX Amplicon Pyrosequencing (bTEFAP) of PCR amplified 16S rDNA. Their results revealed an enormous bacterial diversity residing in the surface sands ( $\geq 10^{3}$ OTUs $/ 5 \mathrm{~g}$ sand) of these two deserts. Members belonging to four phyla: Firmicutes, Proteobacteria, Bacteroidetes and Actinobacteria were found to be the dominant bacterial members of the samples [15]. Using the same sequencing technology, Steven et al., (2013) characterized the bacterial communities of bio crusts in water tracks of the Artic polar region. They suggested that the water tracks in permafrost soils represent a novel ecosystem for microbial and nutrient diffusion from soils to freshwater ecosystems [16].

We report here our results examining the bacterial diversity of the rhizosphere of pioneer plants ( $\mathrm{n}=4)$, plus a nonrhizosphere sand sample $(n=1)$, of the Jizan desert area in Saudi Arabia. We compared the bacterial communities among these samples using pyrosequencing of PCR amplified DNA of V1-V3 regions of 16S rDNA from total genomic DNA extracted from these five samples. The sequences were subsequently analyzed by bioinformatic tools and we determined the richness and diversity of each sample in relation with those of the other hot desert sands.

\section{MATERIALS AND METHODS}

\section{Sample Collection}

The Jizan region ( $\left.16^{\circ} 90^{\prime} \mathrm{N} 42^{\circ} 58^{\prime} \mathrm{E}\right)$ covers a superficial area of $11,671 \mathrm{~km}^{2}$ and comprises of a $4 \mathrm{~km}$ long and 500 $\mathrm{m}$ wide stretch of intertidal mud and sand flats between Jizan port and the northern outskirts of the city of Jizan in Saudi Arabia [17]. With an altitude of $4 \mathrm{~m}$ [18], Jizan is located in the south western part of Saudi Arabia where the Red Sea reaches its maximum width (about $360 \mathrm{~km}$ ) [19]. The temperature (period 2000-2010) is seasonal, with a maximum annual average in summer (June-September) of $45.3^{\circ} \mathrm{C}$ and a minimum annual average in winter (December-February) of $11.9^{\circ} \mathrm{C}$. The mean annual temperature average is $31.6^{\circ} \mathrm{C}$. Total annual rainfall is approximately $130 \mathrm{~mm}[20]$. The rhizosphere from four pioneer plants (Panicum turgidum Forssk. (Graminea, perennial) (Pt); Tribulus pentandum Forssk. (Zygophyllaceae, annual) (Tp); Tribulus terrestris L. (Zygophyllaceae, annual) (Tt), Zygophyllum simplex L. (Zygophyllaceae, annual) (Zs) [21, 22] and one sample of soil (Ss) on a sandy terrain were collected near Jizan (N16 ${ }^{\circ}$ 52.656' E $042^{\circ} 36.972^{\prime}$ ) on march, 2012 (Fig. 1). Triplicate samples were taken from the rhizosphere or soil with the sand surface temperature at $37^{\circ} \mathrm{C}$, and $48 \%$ relative humidity for the samples. The terrain showed poor vegetation, with well separated individual plants. The control soil sample was taken at a site that was $5 \mathrm{~m}$ from any other vegetation. Intact plants, containing their $5 \mathrm{~cm}$ rhizosphere, were completely extracted with a small shovel, carefully without disrupting the root system. The rhizosphere was defined by separating the roots from the surrounding soil by carefully removing the entire plant with intact roots and subsequently rinsing with sterilized $\mathrm{H}_{2} \mathrm{O}$. Chemical analyses of these five samples were performed at the Biochemistry Laboratory at Wageningen University, Netherlands (Table 1).

\section{DNA Extraction}

Genomic DNA was extracted from each sample using a protocol adapted from that of Zhou et al., (1995) [23]. Five grams of sand sample were rehydrated in $1 \mathrm{ml}$ of 1/4 TS (Tryptic Soy) Broth. To extract DNA, $13.5 \mathrm{ml}$ of extraction buffer (0.1M Tris/ $\mathrm{HCl} \mathrm{pH} 8,0.1 \mathrm{M}$ EDTA pH 8, 0,1 $\mathrm{M} \mathrm{Na}_{2} \mathrm{PO}_{4}, 1.5 \mathrm{M} \mathrm{NaCl}, 1 \%$ [w/v] CTAB (Cetyltrimethylammonium bromide) containing $50 \mu \mathrm{l}$ of self-digested Pronase $(20 \mathrm{mg} / \mathrm{ml})$ and $10 \mu \mathrm{lof}$ RNAse A (10 mg/ml) were incubated for 2$\mathrm{h}$ at $37^{\circ} \mathrm{C}$ with shaking. Subsequently, $2.5 \mathrm{ml}$ of $20 \% \mathrm{SDS}$ [w/v] was added and a further incubation for $2-\mathrm{h}$ at $65^{\circ} \mathrm{C}$ was performed. The supernatant fluid was collected after a 20 min centrifugation at $6000 \times \mathrm{g}$ at room temperature. A further extraction was performed on the pellet with $4.5 \mathrm{ml}$ of extraction buffer and $0.5 \mathrm{ml}$ of $20 \%$ SDS, mixed by vortexing for $10 \mathrm{~s}$, followed by incubation for $10-\mathrm{min}$ at $65^{\circ} \mathrm{C}$ and centrifugation for $15 \mathrm{~min}$ at $6000 \times \mathrm{g}$. The supernatant fluids were then combined and mixed. The nucleic acids were extracted by the addition of an equal volume of chloroform/isoamyl 
alcohol (24:1), and, after centrifugation for $20 \mathrm{~min}$ at $6000 \times \mathrm{g}$, the aqueous phase containing the nucleic acids was removed. Then, 0.6 volume of isopropanol was added and a $1 \mathrm{~h}$ incubation at room temperature was performed to precipitate the DNA. Following this, centrifugation for $20 \mathrm{~min}$ at $13000 \times \mathrm{g}$ was performed. The DNA pellet was washed with $1 \mathrm{ml}$ of $70 \%$ ethanol and centrifuged at $11000 \times \mathrm{g}$ for $5 \mathrm{~min}$ at $4^{\circ} \mathrm{C}$. The DNA pellet was then dried and resuspended in $50 \mu \mathrm{l} 1 / 10 \mathrm{TE}$ buffer $(1 \mathrm{mM}$ Tris- $\mathrm{HCl} \mathrm{pH} 8,0.1 \mathrm{mM} \mathrm{Na}$ EDTA pH 8$)$ and incubated overnight at $4^{\circ} \mathrm{C}$ and then stored at $-20^{\circ} \mathrm{C}$.

Table 1. Physical and chemical properties of the five desert sand samples.

\begin{tabular}{|l|l|l|l|l|l|}
\hline \multirow{2}{*}{ Physical and chemical properties } & \multicolumn{3}{c|}{ Sample } \\
\cline { 2 - 7 } & \multicolumn{1}{|c|}{ Pt } & \multicolumn{1}{c|}{ Tp } & \multicolumn{1}{c|}{ Tt } & \multicolumn{1}{c|}{ Zs } & \multicolumn{1}{c|}{ Ss } \\
\hline $\mathrm{C}(\mathrm{mg} / \mathrm{kg})$ & 11 & 11 & 15 & 12 & 14 \\
\hline $\mathrm{N}-\mathrm{NH} 4(\mathrm{mg} / \mathrm{Kg})$ & 1.1 & 1.3 & 1.2 & 1.1 & 1.7 \\
\hline $\mathrm{N}-(\mathrm{NO} 3+\mathrm{NO} 2)(\mathrm{mg} / \mathrm{Kg})$ & 0.7 & 1.6 & 2.5 & 1.8 & 1.2 \\
\hline $\mathrm{P}(\mathrm{mg} / \mathrm{kg})$ & 2.1 & 2 & 3 & 1.7 & 1.7 \\
\hline $\mathrm{K}(\mathrm{mg} / \mathrm{kg})$ & 33 & 54 & 59 & 38 & 48 \\
\hline $\mathrm{pH}$ & 7.28 & 7.69 & 7.55 & 7.29 & 7.38 \\
\hline
\end{tabular}

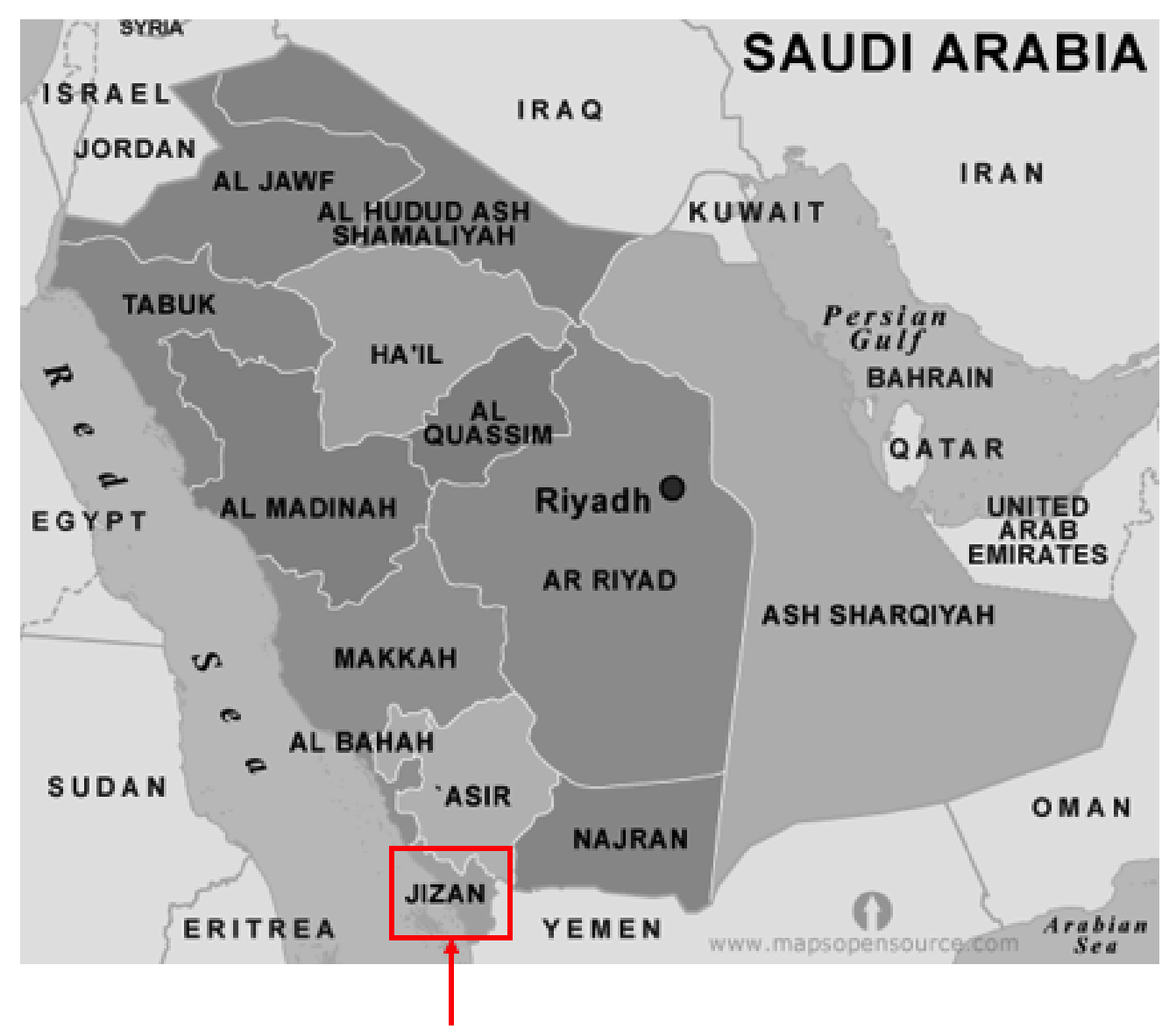

Fig. (1). Jizan desert area sampling site (red) located at N16 52.656 E $042^{\circ} 36.972$ ', Saudi Arabia. Image source: www.mapsopensource.com/saudi-arabia-map-black-and-white.html

\section{Bacterial Tag-Encoded PCR and GS Junior Amplicon Pyrosequencing (BTEGAP)}

The $16 \mathrm{~S}$ rDNA of bacteria was amplified using an initial concentration of $10 \mathrm{ng} / \mu \mathrm{l}$ of the total extracted DNA. PCR reactions $(25 \mu \mathrm{l}$ each) were performed using the universal $16 \mathrm{~S}$ rDNA bacterial primers 27F (5'-Ad.A + GAGTTTGATCMTGGCTCAG-3') and 518R (5'-Ad.B + xxxxxxxxxx + WTTACCGCGGCTGCTGG-3'), where the 
Ad. A and Ad. B represent the adaptors for pyrosequencing (Roche/454), and the xxxxxxxxxx represents ten nucleotide sequence MIDs (multiplex identifiers) for sample identification barcoding. Two different thermostable DNA polymerases were used in the PCR amplifications: (I) AccuPOL ${ }^{\mathrm{TM}} \mathrm{DNA}$ Polymerase (Ampliqon, Denmark): $95^{\circ} \mathrm{C}$ for 2min, followed by 30 cycles of $95^{\circ} \mathrm{C}$ for $30 \mathrm{~s}$ (denaturation), $54^{\circ} \mathrm{C}$ for $30 \mathrm{~s}$ (annealing), $72^{\circ} \mathrm{C}$ for 1 min (polymerization), and a final extension is performed at $72^{\circ} \mathrm{C}$ for 10 -min; (II) Phire Hot Start II DNA Polymerase (Thermo Scientific, Sweden): $98^{\circ} \mathrm{C}$ for $2 \mathrm{~min}$ followed by 30 cycles of $98^{\circ} \mathrm{C}$ for $10 \mathrm{~s}$ (denaturation), $56^{\circ} \mathrm{C}$ for $30 \mathrm{~s}$ (annealing), $72^{\circ} \mathrm{C}$ for $15 \mathrm{~s}$ (polymerization), and a final extension is performed at $72^{\circ} \mathrm{C}$ for $10 \mathrm{~min}$. Three tubes of $25 \mu \mathrm{PCR}$ reactions were performed for each thermostable DNA polymerase and each sample using $10 \mathrm{ng}$ DNA, $0.1 \mu \mathrm{M}$ of each primer (SigmaAldrich, MO, USA), $0.2 \mathrm{mM}$ dNTP mix (Fermentas, ON, Canada), 2.5 units of thermostable DNA polymerase for I and 1.25 units of thermostable DNA polymerase for II using the corresponding buffers with each polymerase. The PCR products were then combined by sample and polymerase used, and the amplified 16S DNA fragments were then purified from a 1\% agarose gel using the NucleoSpin Extraction Kit (Macherey-Nagel, Hoerdt, France). Twenty nanograms of purified PCR product from each sample were mixed for pyrosequencing performed on a Roche/454 GS Junior Pyrosequencer (Department of Biology, University of Oulu, Finland).

\section{Data Analysis}

Raw DNA sequences were extracted and selected by their length (200-600 bp) using mothur software [24]. Sequences were also trimmed and retained if they contained no ambiguous base, no homopolymers $\geq 8$ and no more than one mismatch to the sequencing primer. Adaptor sequences were removed from the sequences using the cutadapt tool implemented on the Galaxy server of the Institut de Génétique et Microbiologie (IGM) of the Université Paris-Sud (http://galaxy.igmors.u-psud.fr/). A second trimming, using a 90\% quality score with $>25$, was performed using Condetri V_2.2 [25]. The sequences were screened for potential chimeric sequences with the Decipher web tool (http://decipher.cee.wisc.edu) [26]. Sequences were classified to the genus level using the Greengenes 2013 release database (202,421 bacterial and archaea sequences) at an $80 \%$ confidence threshold with mothur and using the RDP-II Naïve Bayesian Classifier [27]. To estimate the bacterial population richness and diversity, the RDPII pyro site (https://pyro.cme.msu.edu/index.jsp) was used to calculate the Chao1 estimator and Shannon diversity index. The Jaccard index was also estimated and the relative abundance of operational taxonomic units (OTUs) were determined using a 0.03 distance limit (97\% similarity) by clustering on RDP's pyrosequencing pipeline. All sequences have been deposited in the GenBank Sequence Read Archive (SRA) under the SRP049954 accession number.

Table 2. Number of Treated Sequences, Average Length, OTUs, Richness and Diversity for Each Sample.

\begin{tabular}{|c|c|c|c|c|c|c|}
\hline Sample name & $\begin{array}{c}\text { Number of } \\
\text { Sequences }\end{array}$ & Number of Sequences After Trimming & Average Sequences Length & OTUs & Chao1 & Shannon Index \\
\hline $\mathrm{Pt}$ & 5,363 & 4,361 & 472 & 319 & 637 & 2.25 \\
\hline $\mathrm{Tp}$ & 4,941 & 4,031 & 469 & 900 & 1,754 & 5.62 \\
\hline $\mathrm{Tt}$ & 6,145 & 4,814 & 462 & 737 & 1,245 & 4.89 \\
\hline $\mathrm{Zs}$ & 3,106 & 2,185 & 470 & 613 & 1,282 & 5.26 \\
\hline $\mathrm{Ss}$ & 3,690 & 2,622 & 472 & 961 & 2,026 & 6.18 \\
\hline
\end{tabular}

\section{RESULTS}

We examined five different samples from the Jizan desert area to reveal the environmental properties and relations with the bacterial diversity of the rhizosphere of four pioneer plants growing in this desert area. The five samples were named "Pt" (Paricum turgidum), "Ss" (Soil sample), "Tp" (Tribulus pentandrus), "Tt" (Tribulus terrestris), and "Zs" (Zygophyllum simplex), after the plants (or not) rhizosphere from where they were isolated.

\section{Physical and Chemical Properties of the Rhizosphere and Sand Samples}

The physical and chemical parameters show C, N, P and K element levels and the low carbon compound levels in the five samples. The $\mathrm{pH}$ values ranged from 7.28 in the Pt sample to 7.69 in the Tp sample, suggesting that all samples are close to neutral in $\mathrm{pH}$ (Table $\mathbf{1})$.

\section{Pyrosequencing Data}

Pyrosequencing was performed on the V1-V3 regions of 16S rDNA genes PCR amplified from total DNA extracted 
from the five desert samples. The total number of sequences obtained for the five samples were 23,245, with an average length of 469 bases after trimming. After quality score adjustments, approximately $23 \%$ of the total sequences were removed. The largest number of sequences were obtained from the Tt sample (6,145 sequences), while the Zs sample contained the smallest number of sequences (3,106 sequences) (Table 2 ).

\section{Bacterial Diversity and Richness Analyses}

Diversity statistics for each sample are displayed in Table 2. We measured the sample richness, based on OTUs defined as sequences sharing $\geq 97 \%$ sequence similarity, which represents the potential number of species present in a community. The OTUs, ranging from 319 (Pt sample) to 961 (Ss sample) per sample, were discerned in the 5 samples. The Chaol estimator and the Shannon diversity index were calculated. The richness, assessed with the Chao 1 estimator using a 3\% difference among the sequences, showed that the diversity can significantly vary among rhizospheric plant and soil samples in the same desert. For the samples studied, the richness, estimated by Chao1, ranged from 637 (Pt sample) to 2,016 (Ss sample) OTUs per 5g sample. The Shannon index (Table 2) provides a representation of the diversity in the samples, where the highest diversity level is observed in the Ss sample.

\section{Comparison of Bacterial Community}

The Jaccard index (Table 3) is a statistic that is used to calculate the similarity and richness of a set of samples. We constructed a UPGMA tree generated by the R Statistical Computing Package (Fig. 2). The most distant bacterial population from the samples was found to be the Pt sample, whereas the Tp and Zs samples have the most similar bacterial populations.

\section{Bacterial Phylogenetic Composition}

The bacterial populations in the samples were classified from the $16 \mathrm{~S}$ rDNA sequences with the mothur algorithm using the Greengenes database for bacteria and archaea using the RDP Naïve Bayesian Classifier with an $80 \%$ confidence threshold (Fig. 3). The most abundant bacteria were from the Proteobacteria, with a range from $15 \%$ in the Pt sample to $41.5 \%$ in the Zs sample. The Pt sample has $79.1 \%$ of its members from the Bacteroidetes phylum, while members of this group are not present at $\geq 30 \%$ in the other samples. Following this, we observed members of the Firmicutes, with a range from $0.7 \%$ in the Pt sample to $24.3 \%$ in the Ss sample, plus Actinobacteria with a range from $1.2 \%$ in the Pt sample to $17.6 \%$ in the Tt sample. The unclassified sequences at the phylum level ranged from $0.6 \%$ in the Pt sample to $3.2 \%$ in the Ss sample. Bacteria from a total of 31 genera are represented in Fig. (4). The genera representing less than $1 \%$ of the population were grouped into "other genera". The most abundant bacteria are from genera represented by the Flavobacterium (68.1\%) for the Pt sample, Pontibacter (19.3\%) for the Tt sample and Bacillus with $12.0 \%$ for Tp, $17.9 \%$ for Zs and $18.6 \%$ for the Ss samples. The unclassified sequences, at the genus level, ranged from $6.3 \%$ for the $\mathrm{Pt}$ sample to a $55.5 \%$ for the Ss sample, suggesting many new bacterial groups remain to be discovered.

\section{DISCUSSION}

During the course of the last decade, interest in the study of hot desert microbial diversity has increased [28 - 31] due to global climate change, as arid regions are thought to be more vulnerable. Pyrosequencing of PCR amplified V1$\mathrm{V} 3$ regions of $16 \mathrm{~S}$ rDNA genes from total extracted DNA from the rhizospheric plant samples (Pt. Tp, Tt, Zs) and soil sample (Ss) from the desert area of Jizan (Saudi Arabia) revealed a large bacterial biodiversity in these harsh conditions. We obtained 23,245 high quality sequences, which we classified at the phylum and genus levels, and observed differences among the bacterial communities of the five samples studied. It is important to note that the five samples came from different sites of the same desert, and included the rhizosphere of four different pioneer plants and one surface sand sample. The surface sand sample showed the highest level of unclassified sequences from the phylum to the genus level, though the reason for this is not clear at the current time [32]. 


\section{Distance}

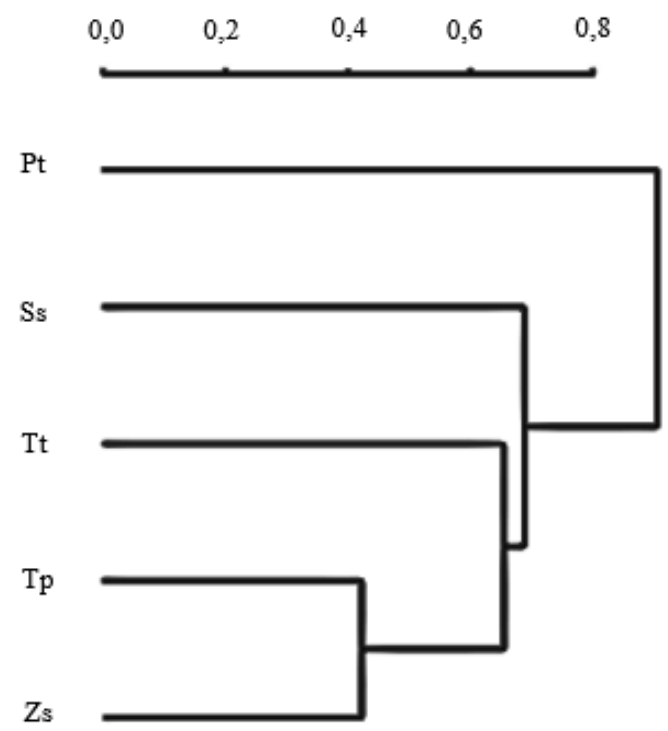

Fig. (2). Jaccard's distance tree of the bacterial populations among the five samples ( $\geq 97 \%$ sequence similarity level) from the Jizan desert. The tree was generated on the RDP website using the R Statistical Computing Package (UPGMA).

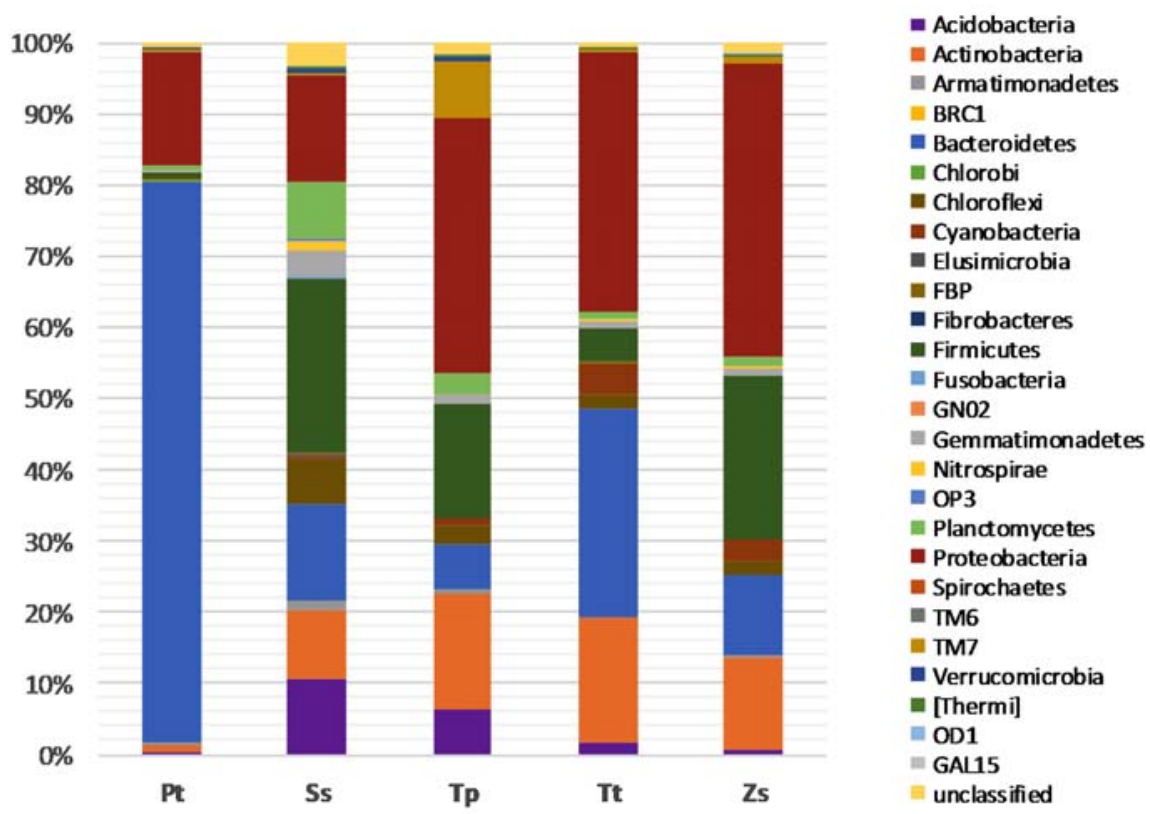

Fig. (3). Taxonomic classification of bacterial sequences at the phylum level from the five Jizan desert sand samples. See the Materials and Methods section for details.

Table 3. Number of treated sequences, average length, OTUs, richness and diversity for each sample.

\begin{tabular}{|c|c|c|c|c|c|}
\hline Sample name & Ss & Tp & Tt & Zs & Pt \\
\hline $\mathrm{Ss}$ & 0 & - & - & - & - \\
\hline $\mathrm{Tp}$ & 0.655 & 0 & - & - & - \\
\hline $\mathrm{Tt}$ & 0.677 & 0.647 & 0 & - & - \\
\hline $\mathrm{Zs}$ & 0.728 & 0.422 & 0.662 & 0 & - \\
\hline $\mathrm{Pt}$ & 0.848 & 0.952 & 0.911 & 0.905 & 0 \\
\hline
\end{tabular}

Five chemical parameters were examined in our samples: total $\mathrm{C}, \mathrm{N}-\mathrm{NH}_{4}, \mathrm{~N}-\left(\mathrm{NO}_{3}+\mathrm{NO}_{2}\right)$, total $\mathrm{P}$ and total $\mathrm{K}$. These factors have been recognized as soil variables that can affect microbial community composition. In particular, the variety of organic compounds released by plants has been postulated to be one of the key factors affecting the diversity 
of microorganisms in the rhizosphere of different plant species $[3,33]$. The levels of phosphorus in the soil can explain some variability in the metabolism and composition of the microbial community, as it may be a limiting micro-nutrient $[34,35]$. It has been reported that the $\mathrm{pH}$ in arid land soils is alkaline [3]. In our five samples, the $\mathrm{pH}$ ranged between 7.28 and 7.69, and is thus considered to be only slightly alkaline. The $\mathrm{pH}$ can be an important factor in the composition of the bacterial community and it has been reported that a higher diversity in soils is found in samples with near neutral pHs [36].

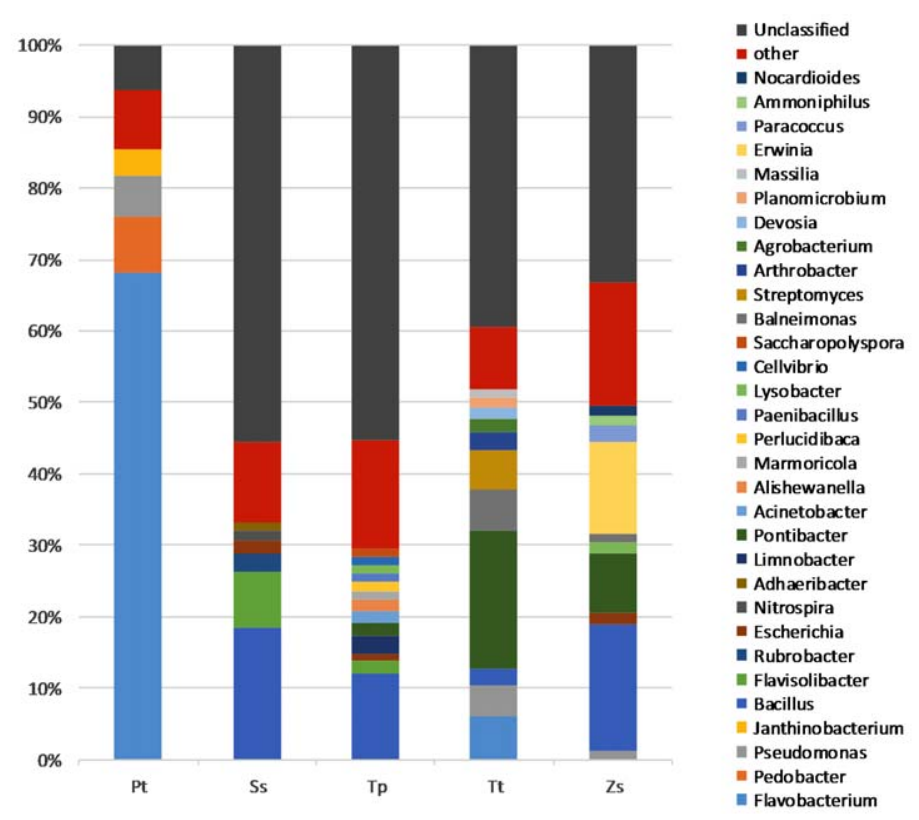

Fig. (4). Taxonomic classification of bacterial sequences at the genus level from the five Jizan desert sand samples. Only genera with members representing $\geq 1 \%$ of the population are shown. See the Materials and Methods section for details.

Here, we used DNA sequencing to discern microbial populations of V1-V3 variable regions of PCR amplified 16S rDNA, as it has been reported to perform well for bacterial assignments in a wide range of datasets [37].

We examined the bacterial richness and diversity in each sample using the Chaol estimator [38] and found a large inter-sample variability (from 319 to 961 OTUs) in the five samples from the same desert. It should be noted that the analysis of these five samples may not be representative of the total microbial diversity of the Jizan desert. These results revealed that the surface sand (Ss) sample had the lowest number of high quality sequences, but also the largest number of OTUs. These results suggest that the number of sequences generated from high throughput sequencing is not always a limiting factor for estimating the total bacterial diversity, though this sample did contain the largest number of unclassified sequences. The Jaccard index was calculated for our samples and the deduced UPGMA tree showed a significant distance among the five different samples and less apparent relations with the rhizosphere plant family.

For the 27 phyla found in all the samples, the most abundant members in three of the samples (Tp, Tt and Zs) belonged to the Proteobacteria phylum. Several studies have shown that members of this phylum are highly represented in desert environments, such as the Sonoran [39], Gobi [34], Namib [40], Atacama [31] and Tataouine deserts [32]. However, the Pt sample revealed that $79.1 \%$ of bacterial members belonged to the Bacteroidetes phylum, while the members of the genus Flavobacterium represent $68.1 \%$ of the OTUs. Members of the Flavobacterium genera are widespread in aquatic and terrestrial environments and can play an important role in the degradation of organic matter. They are also abundant in the rhizosphere of agricultural crops and can be associated with the stimulation of plant resistance to disease [41, 42]. The soil sample (Ss) showed Firmicutes as the major phylum, with $24.3 \%$ of the total sequences, and members of the genus Bacillus representing the major genus with $18.6 \%$ of the total sequences. The differences of bacterial diversity in deserts can thus be highly variable and can depend on soil characteristics and sampling location, among others [43]. Interestingly, the biggest differences in bacterial composition were observed in the grass Panicum turgidum when compared to both the free soil sample and the rhizosphere of three different dicotyl species. These results suggest that both environment and plant species can contribute to the composition of the plant specific rhizosphere microbiome. 


\section{CONCLUSION}

Our study of the bacterial diversity of selected rhizosphere and surface sand samples from the Jizan desert in Saudi Arabia found that there is a diverse bacterial community composition of the rhizosphere of four pioneer plants in this desert, comparable to that seen of non-rhizosphere surface sand sample. Within the five samples, members belonging to the Proteobacteria phylum were the most abundant in the Tp, Tt and Zs samples, the Firmicutes for the Ss sample and Bacteroidetes for the Pt sample. There were also differences in the composition of the less abundant community members among the five different samples collected from the Jizan desert in Saudi Arabia. These results show that the diversity of desert sand microbiomes can vary with environmental conditions, and thus have implications for studies on sandstone monument bacterial communities.

\section{CONFLICT OF INTEREST}

The authors confirm that this article content has no conflict of interest.

\section{ACKNOWLEDGEMENTS}

We thank all the members of the Laboratoire de Génomique et Biodiversité Microbienne des Biofilms (LGBMB) of the Institute of Integrative Biology of the Cell (I2BC) for interesting discussions, comments and suggestions. This work was supported by the Centre National de la Recherche Scientifique (CNRS), France.

\section{REFERENCES}

[1] Azua-Bustos, A.; Urrejola, C.; Vicuña, R. Life at the dry edge: microorganisms of the Atacama Desert. FEBS Lett., 2012, 586(18), 2939-2945.

[http://dx.doi.org/10.1016/j.febslet.2012.07.025] [PMID: 22819826]

[2] Prestel, E.; Regeard, C.; Salamitou, S.; Neveu, J.; Dubow, M.S. The bacteria and bacteriophages from a Mesquite Flats site of the Death Valley desert. Antonie van Leeuwenhoek, 2013, 103(6), 1329-1341. [http://dx.doi.org/10.1007/s10482-013-9914-4] [PMID: 23559041]

[3] Collins, S.L.; Sinsabaugh, R.L.; Crenshaw, C. Pulse dynamics and microbial processes in aridl and ecosystems. J. Ecol., 2008, 96(3), 413-420. [http://dx.doi.org/10.1111/j.1365-2745.2008.01362.x]

[4] Zeglin, L.H.; Dahm, C.N.; Barrett, J.E.; Gooseff, M.N.; Fitpatrick, S.K.; Takacs-Vesbach, C.D. Bacterial community structure along moisture gradients in the parafluvial sediments of two ephemeral desert streams. Microb. Ecol., 2011, 61(3), 543-556. [http://dx.doi.org/10.1007/s00248-010-9782-7] [PMID: 21153024]

[5] Marasco, R.; Rolli, E.; Ettoumi, B.; Vigani, G.; Mapelli, F.; Borin, S.; Abou-Hadid, A.F.; El-Behairy, U.A.; Sorlini, C.; Cherif, A.; Zocchi, G.; Daffonchio, D. A drought resistance-promoting microbiome is selected by root system under desert farming. PLoS One, 2012, 7(10), e48479.

[http://dx.doi.org/10.1371/journal.pone.0048479] [PMID: 23119032]

[6] Prashar, P.; Kapoor, N.; Sachdeva, S. Rhizosphere: its structure, bacterial diversity and significance. Rev. Environ. Sci. Biotechnol., 2013, 13(1), 63-77.

[http://dx.doi.org/10.1007/s11157-013-9317-z]

[7] Iovieno, P.; Båth, E. Effect of drying and rewetting on bacterial growth rates in soil. FEMS Microbiol. Ecol., 2008, 65(3), $400-407$. [http://dx.doi.org/10.1111/j.1574-6941.2008.00524.x] [PMID: 18547324]

[8] Youssef, N.H.; Elshahed, M.S. Diversity rankings among bacterial lineages in soil. ISME J., 2009, 3(3), 305-313. [http://dx.doi.org/10.1038/ismej.2008.106] [PMID: 18987677]

[9] Hartmann, A.; Rothballer, M.; Schmid, M. Lorenz Hiltner, a pioneer in rhizosphere microbial ecology and soil bacteriology research. Plant Soil, 2007, 312(1-2), 7-14.

[http://dx.doi.org/10.1007/s11104-007-9514-z]

[10] Barriuso, J.; Solano, B.R.; Lucas, J.A.; Lobo, A.P.; García-villaraco, A.; Mañero, F.J. Ecology, Genetic Diversity and Screening Strategies of Plant Growth Promoting Rhizobacteria (PGPR). In: Plant-Bacteria Interactions. Strategies and Techniques to Promote Plant Growth; Ahmad, I.; Pichtel, J.; Hayat, S., Eds.; Wiley-VCH Verlag GmbH \& Co. KGaA.: Weinheim, 2008; pp. 1-17. [http://dx.doi.org/10.1002/9783527621989.ch1]

[11] Antoun, H.; Prévost, D. Ecology Of Plant Growth Promoting Rhizobacteria. In: PGPR: Biocontrol and Biofertilization; Siddiqui, Z.A., Ed.; Springer: Dordrecht, 2005; pp. 1-38.

[12] Amann, R.I.; Ludwig, W.; Schleifer, K.H.; Amann, R.I.; Ludwig, W. Phylogenetic identification and in situ detection of individual microbial cells without cultivation. Microbiol. Rev., 1995, 59(1), 143-169. [PMID: 7535888]

[13] Liu, L; Li, Y; Li, S Comparison of next-generation sequencing systems J. Biomed. Biotechnol., 2012. $012: 251364$ 
[14] Zhang, W.; Zhang, G.; Liu, G.; Dong, Z.; Chen, T.; Zhang, M.; Dyson, P.J.; An, L. Bacterial diversity and distribution in the southeast edge of the Tengger Desert and their correlation with soil enzyme activities. J. Environ. Sci. (China), 2012, 24(11), $2004-2011$. [http://dx.doi.org/10.1016/S1001-0742(11)61037-1] [PMID: 23534235]

[15] An, S.; Couteau, C.; Luo, F.; Neveu, J.; DuBow, M.S. Bacterial diversity of surface sand samples from the Gobi and Taklamaken deserts. Microb. Ecol., 2013, 66(4), 850-860. [http://dx.doi.org/10.1007/s00248-013-0276-2] [PMID: 23963222]

[16] Steven, B.; Lionard, M.; Kuske, C.R.; Vincent, W.F. High bacterial diversity of biological soil crusts in water tracks over permafrost in the high arctic polar desert. PLoS One, 2013, 8(8), e71489.

[http://dx.doi.org/10.1371/journal.pone.0071489] [PMID: 23967218]

[17] Newton, S.F. Kingdom of Saudi Arabia. In: Evans MI. (compiler), Important Bird Areas of the Middle East; BirdLife Conservation Series No.2. BirdLife International: Cambridge, U.K., 1994; pp. 277-311.

[18] Almazroui, M.; Islam, M.N.; Jones, P.D.; Athar, H.; Rahman, M.A. Recent climate change in the Arabian Peninsula: Seasonal rainfall and temperature climatology of Saudi Arabia for 1979-2009. Atmos. Res., 2012, 111, 29-45. [http://dx.doi.org/10.1016/j.atmosres.2012.02.013]

[19] Alwelaie, A.N.; Chaudary, S.A.; Alwetaid, Y. Vegetation of some Red Sea Islands of the Kingdom of Saudi Arabia. J. Arid Environ., 1993, 24, 287-296. [http://dx.doi.org/10.1006/jare.1993.1025]

[20] Masrahi, YS; Al-Turki, TA; Sayed, OH Geographical distribution and chorology of grasses in the Arabian Peninsula. Flora - Morphol. Distrib. Funct. Ecol. Plants, 2012, 207(4), 250-6. [http://dx.doi.org/10.1016/j.flora.2011.11.007]

[21] Hegazyt, A.K.; Zilay, A.M. Vegetation-soil relationships in Tihamah coastal plains of Jazan region, Saudi Arabia. J. Arid Environ., 1995, 30, $161-174$. [http://dx.doi.org/10.1016/S0140-1963(05)80067-9]

[22] Salama, F.; El-Ghani, M.A.; El-Tayeh, N. Vegetation and soil relationships in the inland wadi ecosystem of central Eastern Desert, Egypt. Turk. J. Bot., 2013, 37, 489-498.

[23] Zhou, J.; Bruns, M.A.; Tiedje, J.M. DNA recovery from soils of diverse composition. Appl. Environ. Microbiol., 1996, 62(2), 316-322 [PMID: 8593035]

[24] Schloss, P.D.; Westcott, S.L.; Ryabin, T.; Hall, J.R.; Hartmann, M.; Hollister, E.B.; Lesniewski, R.A.; Oakley, B.B.; Parks, D.H.; Robinson, C.J.; Sahl, J.W.; Stres, B.; Thallinger, G.G.; Van Horn, D.J.; Weber, C.F. Introducing mothur: open-source, platform-independent, community-supported software for describing and comparing microbial communities. Appl. Environ. Microbiol., 2009, 75(23), 7537-7541. [http://dx.doi.org/10.1128/AEM.01541-09] [PMID: 19801464]

[25] Smeds, L.; Künstner, A. ConDeTri--a content dependent read trimmer for Illumina data. PLoS One, 2011, 6(10), e26314 [http://dx.doi.org/10.1371/journal.pone.0026314] [PMID: 22039460]

[26] Wright, E.S.; Yilmaz, L.S.; Noguera, D.R. DECIPHER, a search-based approach to chimera identification for 16S rRNA sequences. Appl. Environ. Microbiol., 2012, 78(3), 717-725. [http://dx.doi.org/10.1128/AEM.06516-11] [PMID: 22101057]

[27] Wang, Q.; Garrity, G.M.; Tiedje, J.M.; Cole, J.R. Naive Bayesian classifier for rapid assignment of rRNA sequences into the new bacterial taxonomy. Appl. Environ. Microbiol., 2007, 73(16), 5261-5267. [http://dx.doi.org/10.1128/AEM.00062-07] [PMID: 17586664]

[28] Connon, S.A.; Lester, E.D.; Shafaat, H.S.; Obenhuber, D.C.; Ponce, A. Bacterial diversity in hyperarid Atacama Desert soils. J. Geophys. Res., 2007, 112(G4), G04S17. [http://dx.doi.org/10.1029/2006JG000311]

[29] Chanal, A.; Chapon, V.; Benzerara, K.; Barakat, M.; Christen, R.; Achouak, W.; Barras, F.; Heulin, T. The desert of Tataouine: an extreme environment that hosts a wide diversity of microorganisms and radiotolerant bacteria. Environ. Microbiol., 2006, 8(3), 514-525. [http://dx.doi.org/10.1111/j.1462-2920.2005.00921.x] [PMID: 16478457]

[30] Neilson, J.W.; Quade, J.; Ortiz, M.; Nelson, W.M.; Legatzki, A.; Tian, F.; LaComb, M.; Betancourt, J.L.; Wing, R.A.; Soderlund, C.A.; Maier, R.M. Life at the hyperarid margin: novel bacterial diversity in arid soils of the Atacama Desert, Chile. Extremophiles, 2012, 16(3), 553-566.

[http://dx.doi.org/10.1007/s00792-012-0454-z] [PMID: 22527047]

[31] Neveu, J.; Regeard, C.; DuBow, M.S. Isolation and characterization of two serine proteases from metagenomic libraries of the Gobi and Death Valley deserts. Appl. Microbiol. Biotechnol., 2011, 91(3), 635-644. [http://dx.doi.org/10.1007/s00253-011-3256-9] [PMID: 21494865]

[32] Berg, G.; Smalla, K. Plant species and soil type cooperatively shape the structure and function of microbial communities in the rhizosphere. FEMS Microbiol. Ecol., 2009, 68(1), 1-13. [http://dx.doi.org/10.1111/j.1574-6941.2009.00654.x] [PMID: 19243436]

[33] Marschner, P.; Yang, C.; Lieberei, R.; Crowley, D.E. Soil and plant specific effects on bacterial community composition in the rhizosphere. Soil Biol. Biochem., 2001, 33, 1437-1445. 
[http://dx.doi.org/10.1016/S0038-0717(01)00052-9]

[34] Elser, J.J.; Schampel, J.H.; Garcia-Pichel, F. Effects of phosphorus enrichment and grazing snails on modern stromatolitic microbial communities. Freshw. Biol., 2005, 50(11), 1808-1825.

[http://dx.doi.org/10.1111/j.1365-2427.2005.01451.x]

[35] Delgado-Baquerizo, M.; Maestre, F.T.; Gallardo, A.; Bowker, M.A.; Wallenstein, M.D.; Quero, J.L.; Ochoa, V.; Gozalo, B.; García-Gómez, M.; Soliveres, S.; García-Palacios, P.; Berdugo, M.; Valencia, E.; Escolar, C.; Arredondo, T.; Barraza-Zepeda, C.; Bran, D.; Carreira, J.A.; Chaieb, M.; Conceição, A.A.; Derak, M.; Eldridge, D.J.; Escudero, A.; Espinosa, C.I.; Gaitán, J.; Gatica, M.G.; Gómez-González, S.; Guzman, E.; Gutiérrez, J.R.; Florentino, A.; Hepper, E.; Hernández, R.M.; Huber-Sannwald, E.; Jankju, M.; Liu, J.; Mau, R.L.; Miriti, M.; Monerris, J.; Naseri, K.; Noumi, Z.; Polo, V.; Prina, A.; Pucheta, E.; Ramírez, E.; Ramírez-Collantes, D.A.; Romão, R.; Tighe, M.; Torres, D.; Torres-Díaz, C.; Ungar, E.D.; Val, J.; Wamiti, W.; Wang, D.; Zaady, E. Decoupling of soil nutrient cycles as a function of aridity in global drylands. Nature, 2013, 502(7473), 672-676.

[http://dx.doi.org/10.1038/nature12670] [PMID: 24172979]

[36] Lauber, C.L.; Hamady, M.; Knight, R.; Fierer, N. Pyrosequencing-based assessment of soil pH as a predictor of soil bacterial community structure at the continental scale. Appl. Environ. Microbiol., 2009, 75(15), 5111-5120. [http://dx.doi.org/10.1128/AEM.00335-09] [PMID: 19502440]

[37] Liu, Z.; DeSantis, T.Z.; Andersen, G.L.; Knight, R. Accurate taxonomy assignments from 16S rRNA sequences produced by highly parallel pyrosequencers. Nucleic Acids Res., 2008, 36(18), e120. [http://dx.doi.org/10.1093/nar/gkn491] [PMID: 18723574]

[38] Chao, A.; Bunge, J. Estimating the number of species in a stochastic abundance model. Biometrics, 2002, 58(3), 531-539. [http://dx.doi.org/10.1111/j.0006-341X.2002.00531.x] [PMID: 12229987]

[39] Nagy, M.L.; Pérez, A.; Garcia-Pichel, F. The prokaryotic diversity of biological soil crusts in the Sonoran Desert (Organ Pipe Cactus National Monument, AZ). FEMS Microbiol. Ecol., 2005, 54(2), 233-245. [http://dx.doi.org/10.1016/j.femsec.2005.03.011] [PMID: 16332322]

[40] Prestel, E.; Salamitou, S.; DuBow, M.S. An examination of the bacteriophages and bacteria of the Namib desert. J. Microbiol., 2008, 46(4), 364-372.

[http://dx.doi.org/10.1007/s12275-008-0007-4] [PMID: 18758725]

[41] Kolton, M.; Green, S.J.; Harel, Y.M.; Sela, N.; Elad, Y.; Cytryn, E. Draft genome sequence of Flavobacterium sp. strain F52, isolated from the rhizosphere of bell pepper (Capsicum annuum L. cv. Maccabi). J. Bacteriol., 2012, 194(19), 5462-5463. [http://dx.doi.org/10.1128/JB.01249-12] [PMID: 22965088]

[42] Kolton, M.; Meller Harel, Y.; Pasternak, Z.; Graber, E.R.; Elad, Y.; Cytryn, E. Impact of biochar application to soil on the root-associated bacterial community structure of fully developed greenhouse pepper plants. Appl. Environ. Microbiol., 2011, 77(14), 4924-4930. [http://dx.doi.org/10.1128/AEM.00148-11] [PMID: 21622786]

[43] Saul-Tcherkas, V.; Unc, A.; Steinberger, Y. Soil microbial diversity in the vicinity of desert shrubs. Microb. Ecol., 2013, 65(3), 689-699. [http://dx.doi.org/10.1007/s00248-012-0141-8] [PMID: 23192699]

\begin{tabular}{lll}
\hline Received: June 15, 2015 & Revised: June 21, 2015 Accepted: July 31, 2015
\end{tabular}

(C) Osman et al.; Licensee Bentham Open.

This is an open access article licensed under the terms of the Creative Commons Attribution-Non-Commercial 4.0 International Public License (CC BY-NC 4.0) (https://creativecommons.org/licenses/by-nc/4.0/legalcode), which permits unrestricted, non-commercial use, distribution and reproduction in any medium, provided the work is properly cited. 